\title{
"Listening for landfall": how silence and fear marginalized the music of the Aran Islands
}

\section{Deirdre Ní Chonghaile}

\section{Q OpenEdition \\ 1 Journals}

\section{Electronic version}

URL: http://journals.openedition.org/etudesirlandaises/3734

DOI: 10.4000/etudesirlandaises.3734

ISSN: 2259-8863

\section{Publisher}

Presses universitaires de Rennes

\section{Printed version}

Date of publication: 30 June 2014

Number of pages: 41-55

ISBN: 978-2-7535-3449-0

ISSN: 0183-973X

\section{Electronic reference}

Deirdre Ní Chonghaile, " "Listening for landfall": how silence and fear marginalized the music of the Aran Islands », Etudes irlandaises [Online], 39-1 | 2014, Online since 30 June 2016, connection on 30 April 2019. URL : http://journals.openedition.org/etudesirlandaises/3734; DOI : 10.4000/ etudesirlandaises.3734 


\title{
"Listening for landfall": How Silence and Fear Marginalized the Music of the Aran Islands
}

\author{
Deirdre Ní Chonghaile \\ National University of Ireland Galway
}

Abstract

The Aran Islands off the west coast of Ireland are a palimpsest bearing layers of representations in a myriad of forms including literature, film, television, radio, photography, and art, representations created by islanders and visitors. In the resulting Aran canon, which is dominated by visiting authors instead of local authors, the music of the Aran Islands - which is classified here as Irish traditional or folk music - has, however, been marginalised. This is surprising because both Irish traditional music and Aran itself are often cast independently of each other as entities that depict Irishness, entities that are, in fact, for many observers, exemplars of that identity. This article questions how the visitor's experience of listening in Aran, which differs radically from that of locals, has contributed to the marginalisation of local music in the wider discourse and practice of Irish traditional music and Irish culture. It focuses on two of the forces at work in the marginalisation of the music of Aran. They are an appetite for silence and the silencing of music. Referencing the work of John Millington Synge, Kuno Meyer, Fr. Eoghan Ó Gramhnaigh and Andrew McNeillie, and that of the local poet Máirtín Ó Direáin, it considers the motives and fears that led visitors and islanders to treat the music of Aran as they did. This article is ultimately about how the act of listening to the world around us has a fundamental impact on how we represent islands and their cultures. Acknowledging the strong association between music and place that permeates the discourse of Irish traditional music and how, through the uniquely visceral experience of listening, that association has come to be so pervasive, it questions how and why, through the choices we make when we are listening, we perform notions of authenticity, musicality, and identity.

Keywords: Music; John Millington Synge; history of representations; Aran islands

\section{Résumé}

Les Illes d'Aran, sur la côte ouest de l'Irlande, sont un palimpseste à travers lequel on distingue de multiples niveaux de représentation sous une myriade de formes dont la littérature, le cinéma, la télévision, la radio, la photographie et les arts plastiques, représentations créées autant par les habitants que les visiteurs. Dans le canon artistique qui en résulte, et qui est dominé plutôt par les auteurs visiteurs que les auteurs résidents, la musique des Îles d'Aran - qui est qualifiée ici de musique traditionnelle ou populaire - a été marginalisée. Ceci est surprenant dans la mesure où les musiques traditionnelles irlandaise et de l'Île d'Aran elle-même sont souvent considérées en tant qu'entités indépendantes, alors que l'une comme l'autre caractérisent l'Irlande pour beaucoup d'observateurs. Cet article pose la question de savoir en quoi l'expérience d'écoute par les visiteurs des Îles d'Aran, qui est radicalement distincte de celle des habitants, a contribué à marginaliser la musique locale dans la considération et la pratique plus large de la musique traditionnelle et la culture irlan- 
daise. Il se concentre sur les deux forces à l'œuvre dans la marginalisation de la musique d'Aran: l'appétit pour le silence et la mise en sourdine de la musique. En s'appuyant sur les travaux de John Millington Synge, Kuno Meyer, Fr. Eoghan Ó Gramhnaigh et Andrew McNeillie, et sur ceux du poète local Máirtin Ó Direáin, cet article considère les motifs et les peurs qui ont conduit les visiteurs et les insulaires à traiter la musique d'Aran comme ils l'ont fait. Cet article observe, par essence, comment l'acte d'écouter le monde qui nous entoure a une influence fondamentale sur la façon dont nous représentons les îles et leurs cultures. En reconnaissant l'association forte entre la musique et le lieu, qui imprègne le discours sur la musique traditionnelle irlandaise, et comment, à travers l'expérience viscérale de l'écoute, cette association est devenue aussi prévalente; cet article pose la question de savoir comment et pourquoi à travers les choix que nous faisons quand nous écoutons, nous mettons en forme des notions d'authenticité, de musicalité et d'identité.

Mots clés : Musique; John Millington Synge; histoire des représentations; îles d'Aran

Patrick Sheeran called the Aran Islands "a much-traversed erogenous zone", "a place of enchantment" hosting a "recurrent human need for romance, for magic and providential mystery" and yielding to "the necessity to ground such desires in a specific locale" $(1994,302)$. Aran is a palimpsest bearing layers of representations in a myriad of forms - including literature, film, television, radio, photography, and art - that create a canon of work about or relating to Aran (Korff et al., 1994, Ó hEithir 1991). Tim Robinson described this canon in his review of Andrew McNeillie's An Aran Keening: "We will all just have to move up, like cormorants on a rock when another arrives with widespread wings, and, without graceless squawking and pecking, make room for a worthy addition to the canon" (2001). In the resulting Aran canon, which is dominated by visiting authors instead of local authors, the music of the Aran Islands has been marginalized: only a handful of music collectors have visited the islands (including George Petrie and Eugene O’Curry, Fr. Eoghan Ó Gramhnaigh, Holger Pedersen, Fr. Luke Donnellan, Séamus Ennis, Jean Ritchie, Diane Hamilton, and Sidney Robertson Cowell), there are only a few commercial releases of the music of Aran (Cowell 1957, Ronan 1983, Ní Mhiolláin 1989, Comharchumann Árann 1995, Ceol na dTonn 2001, Ní Chonaola 2002, 2005, Ó Conaola 2006, Various 2006), and local musicians rarely travel far afield. This marginalization is surprising because both Irish traditional music and Aran itself are often cast independently of each other as entities that depict Irishness, entities that are, in fact, for many observers, exemplars of Irishness.

The marginalisation of the music of Aran has prompted some observations I would like to share here. The ultimate purpose of this article is not simply to test the veracity of the claims I am making; it is to dwell, for a time at least, on some of the questions they raise. These are questions that remind us that music is, for most of us, a sound or a "humanly organized sound" (Blacking, 1973). We are moved by music, 
physically and emotionally, we feel it, we dance it, we play it, we create it; but, first and foremost, we listen to it. I would like to dwell for a moment on the uniquely visceral experience of listening and to ask: how and why, through the choices we make when we are listening, we perform notions of authenticity, musicality and identity?

The biggest factors in the marginalisation of the music of Aran are: the historically limited capabilities of portable recording technology before mainline electricity was made available in the islands; and the impracticalities of island life - including bad weather, unreliable transport links, the lack of efficient communications, and the lack of electricity. Time, tide, and technology have conspired again and again to challenge the capabilities of those who might otherwise have documented and disseminated the music of Aran. Here, however, I would like to draw attention to two other factors: the treatment of sound and the treatment of music in the Aran canon. To do this within the present confines of space, I will enlist the help of just a few authors whose works will be familiar to many who read about Aran, including John Millington Synge, Andrew McNeillie, Máirtín Ó Direáin, and some others.

\section{An Appetite for Silence}

The Aran canon is dominated by the perspective of the visitor, whose relationship with Aran and with the sights and sounds of Aran is different to that of the islander. The canon features sound and music sometimes in vivid ways (Synge 1907, Mason 1936, MacConghail 1988) but silence, or the absence of human sound or of humanly organised sound, is often identified as an essential, and therefore more valuable, element of Aran (Synge 1907, Robinson 1986, McNeillie 2001). In 1900, John Millington Synge made this identification when he described an instance in which relative silence - certainly the absence of human sound - appeared to him to characterise life in Aran, the people there, and the experience of being there:

I have been down sitting on the pier till it was quite dark. I am only beginning to understand the nights of Inishmaan and the influence they have had in giving distinction to these men who do most of their work after nightfall.

I could hear nothing but a few curlews and other wild-fowl whistling and shrieking in the seaweed, and the low rustling of the waves. It was one of the dark sultry nights peculiar to September, with no light anywhere except the phosphorescence of the sea, and an occasional rift in the clouds that showed the stars behind them. 
The sense of solitude was immense. I could not see or realize my own body, and I seemed to exist merely in my perception of the waves and of the crying birds, and of the smell of seaweed.

When I tried to come home I lost myself among the sandhills, and the night seemed to grow unutterably cold and dejected, as I groped among slimy masses of seaweed and wet crumbling walls.

After a while I heard a movement in the sand, and two grey shadows appeared beside me. They were two men who were going home from fishing. I spoke to them and knew their voices, and we went home together $(1907,82)$.

Andrew McNeillie had a similarly disorienting experience in Aran in 1969, one that helped him to define the place in which he had located himself and his relationship with it in terms of sound and silence; he wrote:

The island's winter storm-wakes sometimes brought fog, and then solitude seemed to intensify in the attendant muffled silence that amplified the crash and back-roar of the sea. You heard the sea as clear as crystal but heard much more the silence that enveloped it and enveloped you. Enormous silence carried you on straining ears, stumbling at the end of the world, listening for landfall, dreaming of the tolling bell. It was like the end of the world when fog came down. Your mind becalmed seemed to creak and echo hollowly under its oppression $(2001,87)$.

Some visitors express a desire for silence in Aran: in The Aran Islands, for example, Synge sometimes distances himself from human sounds, including music, by hearing them as a distant sound $(107,26)$ or through the floor of his upstairs room $(1907,136)$; and, in An Aran Keening, McNeillie walks circuitously towards the less densely populated western end of Árainn, 'bypassing' villages because he "craved the empty seaborne world as if it were a heaven" $(2001,103)$. McNeillie is, in fact, one of many visitors whose search for silence is what has brought them to Aran; his ascetic reason for coming to Aran in 1969 was to draw "as near to matter as I might, to the stones and the weather" $(2001,103)$ :

What was I doing there? It sometimes needed to be asked. Ostensibly I had come to see what it was like and how the people lived upon the island, not in the easy tourist season but at the worst time of the year. I'd come for more obscure reasons too, to put the world behind me and the glib hot-air talk of educated work, to test myself against solitude and hardship. I had not come believing I might stay forever, though now and then I wondered how I might contrive to $(2001,99)$. 
By locating in Aran their desires for silence, for peace and, ultimately, for escape from the noise of more densely populated and urban places, these visitors have disassociated Aran from noise and from sound. They associate the islands, instead, with silence, with quietness, or with the absence of human sound. A wellknown example of this association of Aran with silence as escape and relief is the dream sequence from The Aran Islands (1907, 54-55), in which Synge awakens from a tumultuous, noisy, music-filled dream to find respite in the silence of Aran:

At last with a moment of uncontrollable frenzy I broke back to consciousness and awoke. I dragged myself trembling to the window of the cottage and looked out. The moon was glittering across the bay, and there was no sound anywhere on the island $(1907,55)$.

\section{An Appetite for Spectacle}

The presence or absence of sound in Aran is clearly an important element in the conceptualization and the realization of the place, but it is the tangible and visible aspects of life there - which, by their physicality, become images of Aran - that are valued most in the Aran canon. Indeed, in photography, in film, and even in literature, images dominate sound in the Aran canon (Synge 1907, Flaherty 1934, Bill Doyle 1999, Colman Doyle 2004). The canon reveals that many visitors seek spectacle in Aran. Although its material culture - including currachs and woollen jumpers - is equally iconic, it is the natural environment of Aran in particular - the visually striking physical landscape - that attracts the most attention. Some of the works produced thus far in the twenty-first century, including An Aran Keening by McNeillie (2001) and Window on Aran by Seán Spellissey (2003), demonstrate how Aran has become what Orvar Löfgren termed a "landscape of consumption" (cited in Ó Giolláin 2000, 77).

We can gain some insight into this concept, its nature and its implications, by looking for a moment at another landscape of consumption, Yosemite National Park in California, which inspires rhetoric that echoes that of the Aran canon. Simon Schama describes the "hallowing visitations" to Yosemite by preachers, photographers, artists, and writers who created "the holy park of the West; the site of a new birth; a redemption for the national agony; an American re-creation" $(1995,7)$ - visitors who contributed to an image of Yosemite that is typically unpeopled and, consequently, silent: "we still imagine Yosemite ... with no trace of human presence" $(1995,7)$. The beauty of the place cultivated a longing for the mystery of an untouched wilderness and the institution of a national park in the valley in 1890 eventually legislated for that understanding of the place. The 
archdiocese of sacred wilderness created a new cathedral, a spiritual refuge that resonates with heavenly silence and from which sound, profane and earth-bound - human sound in particular - is banished. This cathedral proffers a peaceful solace that is located, fixed, preserved yet accessible, quiet, and still. Interestingly, if not paradoxically, this vision of the valley was criticized in 1992 by Ansel Adams, the famous photographer who immortalized Yosemite, in a letter he wrote in 1956 to David Brower of the Sierra Club:

The wilderness is not wilderness unless it is reasonably pure: unfortunately, in order to keep it pure we have to occupy it (even in a negative sense). I fear a lot of the wilderness reaction is one of specific personal escapism - but we really do not escape from the realities of life and civilization. We enjoy the wilderness because of the advantages of civilization (Adams 1992: 117).

Adams recognized the tension between the sacred, mute vision of the American West and the hurtful historical truth of the Ahwahneechee, those Native Americans who were driven from Yosemite by the Gold Rush and are since dispossessed, those who have endured the real and negative impact of the vision. Adams also recognized where control of the vision and of the place itself still lies. Of course, the history of Aran is nowhere near as bloody as that of Yosemite, but the tension that Adams observes exists in both places.

Both of these landscapes - Yosemite and Aran - inspire and feed an appetite for spectacle and silence that ultimately marginalises sound and music in the Aran canon ${ }^{1}$. For islanders, however, music is a vital part of life, performed and experienced in times of joy and in times of sorrow, as this local saying indicates: "Gaibhtear fonn le fonn agus fonn le mífhonn" [Songs are sung in joy and songs are sung in sorrow] (T. O'Flaherty 1934, 131). Islanders value music more than silence. This is well illustrated in the poem "Árainn 1947" by Máirtín Ó Direáin, which appears in Appendix I (Ó Direáin 1984b, 16; Ó hEithir 1991, 162-163). In it, he describes a dreadful encounter with silence. On a return visit to his island home, Ó Direáin misses hearing whistling or a song that would have been used to pass the time, to ease a journey, to lighten the mood, or to express oneself. The structure of the poem highlights the dichotomy between sound and silence. Each verse begins with a short, evocative description of sound, each an announcement or fanfare (the translations are my own): "Feadaíl san oíche", "Amhrán aerach", and "Liú áthais ná aitis" - "Whistling at night", "A lively song", "A cry of joy or excitement" - and each verse finishes with the same refrain, a contrasting and echoing evocation of deafening silence, absence, and loss: "An tráth seo thiar/

1. See also Luke Clancy's radio series, Sound Stories, in which Bob Quinn discussed different representations of Conamara through the medium of sound (RTÉ Radio One, 11 October 2007). 
Níor chualas" - "This time in the West/I heard not". Having equated sound and, in particular, music with life, Ó Direáin concludes that silence in Árainn means death for the island: "Ní don óige feasta/An sceirdoileán cúng úd" - "No longer for the young/That narrow windswept island". This interpretation of what sound and silence mean for Aran, which is echoed in at least two other of Ó Direáin's poems - An tEarrach Thiar [The Western Spring] (Ó hAnluain 2002, 27-28) and Dán an Tí [The Poem of the House] (2002, 121-124) - differs radically from that of visitors. But, as long as the contributions of visitors outnumber those of islanders, the appetite for silence will continue to marginalise sound and music in the Aran canon.

\section{The Silencing of Music}

This dynamic between sound and silence in the Aran canon suggests the other factor that contributes to the marginalisation of music in Aran; that is, the silencing of music. To explain this factor, I draw here on the theory presented by Jacques Attali in his book Bruits: essai sur l'économie politique de la musique, wherein he argues that music is a herald of change: "Elle annonce, car elle est prophétique" (1977, 8). In the Aran canon, the heraldic power of music is muted by the majority of contributors. Two contrasting reports on the music performed in Inis Meáin in the autumn of 1889 illustrate how this occurs; the reports were written by the German linguist Kuno Meyer and the Irish-language enthusiast Fr. Eoghan Ó Gramhnaigh who both happened to be holidaying there to improve their Irish. In a letter to his friend Whitley Stokes, Meyer indicates how modernity, he believes, has changed the local song repertoire; his Romantic understanding of modernity in Aran as constituting that which belongs to the world beyond Aran (the evidence of which includes commercialism and mass communication) - an understanding he shares with Ó Gramhnaigh - is typical:

I wish we could write down the tunes they sing here. But neither my sister [Antonie] or I are able to do it. I am afraid they are not as numerous now as they were when you were here [in 1857]. Too many modern songs have come in and crowded them out ${ }^{2}$.

Ó Gramhnaigh shares Meyer's regret at the loss of Irish-language songs in Inis Meáin but he feels a need to temper his regret with the hope that the integrity of the local song tradition is still intact: "Is dócha gur cailleadh cuid de na h-abhrá-

2. Meyer to Stokes, TCD MS10085 (25), cited in Ó Lúing 1991, p. 7. Meyer was himself a singer: "Kuno returned one evening to their camp-fire near Bala, with a Gypsy harper for company, to enliven their proceedings with Welsh melodies, or with the harmonies of penillion singing at which Meyer himself excelled" ("John Sampson (1862-1931)" by Andreas in Journal of the Gypsy Lore Society (XI) 1932, p. 3-4, cited in Ó Lúing 1991, p. 10). 
naibh so ó shoin, acht tá cuid mhór le fagháil fós, go mór-mhór aig na mnáibh" [It is likely that most of these songs were lost since, but there are many still to be found, especially with the women.] (Ó Gramhnaigh 1889-1890, 55). At no point does Ó Gramhnaigh describe an influx of "modern songs" - meaning English-language songs - as Meyer does, for to do so would undermine the idyll of unadulterated Gaelic Inis Meáin, which was then growing in reputation year by year and which Ó Gramhnaigh held in the highest regard:

Do bhidheas in Arainn tri h-uaire. Bhi aithmheula orm, air imtheacht dam, gach uile uair. Aig an $n$ Gaedhilge, aig an aer úr, follain, aig na daoinibh cáirdeambail, bhidheadh an là lán d'aoibhneas ó ghlasadh na maidne go ceo na h-oidhche. Gheobhaidh tú fäilte às sláinte, na fir is laghaighe, an Ghaedhilge is fearr, ins na h-oileánaibh. Bidhim-se feìn ag breathnughadh romham, agus is fada liom go rachfad ann air cuairt aris. 'San am rombainn, is dócha go d-tiocfaidh biseach saoghalta air Árainn; nach m-beidh si chomh bochtuighthe agus chidhmid anois $i$; acht go g-congbhuighidh a daoine go deo an intinn agus an t-anam glé, simplidhe, an croidhe cáirdeambail, teith, atá aca andiu (Ó Gramhnaigh 1889-1890, 55).

I was in Aran three times. I was sorry each time I left. With the Irish [language], with the fresh, healthy air, with the friendly people, the day was full of delight from the dawning of morning to the dimming of night. You will get a welcome and good health, the gentlest of men, the best of Irish [language], in the islands. I myself look ahead, and I long to visit there again. One supposes that, in the future, Aran will improve materially and will not be so impoverished as is now evident; but may its people always retain the intellect, the clear simple soul, the warm kind heart that is theirs today.

He tacitly acknowledges that modernity will bring further changes to Inis Meáin but he does not even infer the assimilation of English songs and other musics that he must have known would inevitably occur if he had not already witnessed it: "Má leanann an saoghal do’n lorg air a bhfuil sé anois, ní mhairfidh na hionmhusa so i bh-fad - gach uile lá tá na seandaoine aig a bh-fuil siad ag fághail bháis, agus muna m-bailimid na sgeulta, na habhráin, na sean-ráidhte, na paidreacha, etc., go tráthamhail, beidh siad air iarraidh gan mhoill” [If life follows the path it is on now, this wealth won't last - every day the old people, who have this wealth, are dying, and if the stories, songs, old sayings, prayers, etc., are not collected in time, they will soon be lost $]^{3}$. With the exception of his proposal that 'good English-language songs' ought to be translated into Irish to bolster the local

3. Eoghan Ó Gramhnaigh, "More Gleanings from the Islands”, Tuam News/Western Advertiser 11 July 1890, p. 4. 
song repertoire, Ó Gramhnaigh writes about local traditions, including music, in terms of loss and not gain ${ }^{4}$. Therefore, we see that both reports align themselves with the contemporary and commonly-held negative attitude to modernisation in Aran, but that one of them effectively silences the music that heralds change.

It seems that Ó Gramhnaigh's conservatism not only encouraged him to censor the music he heard in Aran; it appears also to have led him to alter the text of one of the songs he collected there. The song A Bhean an Tighe na Páirte, which he collected in September 1889 and published in May 1890, was probably known in Inis Meáin by its more common and part-English title, A Landlady na Páirte [Dear Landlady] ${ }^{5}$. Assuming that he did, indeed, translate the title and the first line of the song, then Ó Gramhnaigh admitted his acceptance of the power of music to herald change. He also revealed his concern for the integrity of local culture in Aran, which was - he and his contemporaries and compatriots, the Gaelic Revivalists, believed - under threat from the encroachment of modern, English-speaking culture. At a deeper level lay their collective concern for the popular conception of Aran as a storehouse or stronghold of native Irish culture and, therefore, of Ireland itself. For the sake of the future of native Irish culture, Ó Gramhnaigh and his compatriots believed that both the existence of that culture in Aran and the concept of Aran as the protector of that culture were imperative; as Breandán and Ruairí Ó hEithir observed: "The Aran Islands became an outpost of Irish tradition, a simple, primitive place embodying all that was good of Irish culture and language, a place to be revered and preserved. This picture, of course, owed much to the personal views and motives of those who painted it" (Ó hEithir 1991, 61). By censoring and, in all probability, altering his representations of the music of Aran, Ó Gramhnaigh acted in the hope that Aran would be saved from becoming yet another sepulchre of Gaelic Ireland.

Ó Gramhnaigh's efforts to temper his observations of music in Inis Meáin between 1885 and 1889 suggest that the general lack of focus on music in Aran may very well be the result of a focus away from music in Aran because of the ability of music to undermine the integrity of the image of Aran as a storehouse of tradition, culture, and language. There is at least one instance where a contributor recognised the subversive power of music to herald change and chose to exploit it. Unlike his nationalist contemporaries, whose accounts of song in Aran

4. "Ba mhór an gar d'áitibh mar so dá n-déantaoi abhráin maithe Beurla d'aistriughadh go Gaedhilge" [It would be of great benefit to places like this if good English-language songs were translated into Gaelic] (Ó Gramhnaigh 1890a, 55n). In this, Ó Gramhnaigh may also be suggesting that the English songs that were performed in Inis Meáin in 1889 were of dubious quality, a complaint expressed in 1901 by Synge in relation to The White Horse (1907, p. 120-122).

5. See Ní Uallacháin 2003, p. 215-216; Ní Fhlathartaigh 1976, 51 (\#73b) “Trua 'gan mé’s mo stóirín 's teach mór againn i Meiriocá!"; Ní Fhlathartaigh 1976, p. 98-99 (\#143) "Lean Leadaí na Páirte”. 
feature only Irish-language songs ${ }^{6}$, in The Aran Islands, Synge is keen not only to give evidence of English songs in Aran but also to highlight that music, more than other elements of local culture, is a herald of the change that is coming to Aran, the change towards increasing bilingualism and modernisation, as witnessed in Árainn - "in general, I was surprised at the abundance and fluency of the foreign tongue" $(1907,6)$ - and in Inis Meáin - "as these men are bilingual they have a fair notion of what it means to speak and think in many different idioms" (1907: 15). In Inis Oírr in 1901, he wrote: "I am in the south island again, and I have come upon some old men with a wonderful variety of stories and songs, the last, fairly often, both in English and Irish" (1907, 118). Among the songs Synge collected in Aran, there is at least one song in English entitled The White Horse, which he described as "an extraordinary English doggerel rhyme" (1907, 120): "Grotesque as this long rhyme appears, it has, as I said, a sort of existence when it is crooned by the old man at his fireside, and it has great fame in the island" $(1907,122)$. However, instances such as this are so rare as to render them ineffectual in the wider discourse on music in Aran, which, it appears, favoured silence on the elements of musical life in Aran that were antithetical to, and thus had the power to undermine, the celebrated ideal ${ }^{7}$. Ó Gramhnaigh's representation is, in fact, just one example of how music that heralds change is sometimes marginalised in the Aran canon ${ }^{8}$.

6. Music collections created by contemporary visitors - including Eoghan Ó Gramhnaigh (1889-1890), Pádraig Pearse (1898), and, to the best of my knowledge, Holger Pedersen (Munch-Pedersen 1994) - consist entirely of songs in Irish, except for one of Pedersen's transcriptions, which features a verse in English. Úna Ní Fhaircheallaigh's book Smuainte ar Árainn contains many descriptions of musical activities in Árainn and Inis Meáin during the fin-de-siècle period (1902). Finally, secretaries of the local branches of the Gaelic League sometimes described in their minutes the music performed at weekly meetings. Keen to attract as many members as possible with the promise of fun for all, the League liked to encourage and to emphasise musical activities.

7. Consider Norris Davidson's effort to counter the mythologising effect of Man of Aran in his short 1934 film Dancers of Aran / Aran Dance, the rationale for which he gave in a letter to the Connacht Tribune newspaper on 5 October 1935: "A chara, I should like to venture a protest against the criticism of my picture, Dambsa Arann [sic], in the Annsoo agus Annsud column of the 'Connacht Tribune'. Certainly I did not use the best dancers in the island, and certainly I might have used other music, say, 'The Blackbird'. But had I gathered the best dancers in the island and used this music the whole thing would have looked staged and false and not in the least like what it is intended to be, a 'bit of a dance'. It would have fallen in line with a recent picture, 'Irish Hearts', and become just another example of how not to make an Irish film. Instead, I made a film showing Inishmór as it is normally - not as it was eighty years ago, and not as it is on a special day of dancing like the 29th of June, but just showing a phase in the life of a village. I could do everything your correspondent suggests, but the film would cease to be Damhsa Arann, the film of a village which I know intimately. Had the best possible dancing been in question, I would have filmed Feis medalists on their platforms. Seamus Davidson. Donard, Co. Wicklow" (Saturday 12 October 1935, p. 9). Unfortunately, it is not yet known whether or not the film survives so, for now, this subversive effort continues to be muted.

8. In his edition of Scéalta Mháirtín Neile (1994), a collection of stories collected in Árainn by Holger Pedersen over a period of nearly four and a half months from 1895 to 1896, Ole Munch-Pedersen neglected to include the songs that Pedersen transcribed from Marcuisín Mhicil Siúinéara Ó Flaithbheartaigh and others because he did not consider them to be authoritative versions. He was afraid that the inclusion of these songs alongside the better-quality stories would compromise the integrity of the collection of stories. It is important, however, to 
I present here four other instances of such marginalisation as they occur in the work of different contributors who were commentators and collectors of music. The first two examples comment directly on music and the last two examples feature indirect comment.

(1) In 1945, Séamus Ennis chose not to transcribe an Irish-language song he heard in Inis Meáin because he believed it was a local translation from an English original brought to the island by visitors: "ní mé beó anois céard é fhéin, mar níorbh" fhiú liom cuimhne a choinneáil air' [I have no idea now what it was, because I could not be bothered to remember it] (NFC 1297: 63-4).

(2) While the American ethnographer Sidney Robertson Cowell (1903-95) was busy collecting the "Songs of Aran" during her 1955 visit to Árainn (Cowell 1957), she omitted locally-composed songs in Irish - including Ambrán an Chogaidh [The War Song] by Sr Benan alias Mary Sheáinín Aindí Ní Ghoill (d.1994) from Sruthán, Árainn - because they were offered by a singer whose operatic tone sounded untraditional to her ears:

Mrs. Kate Faherty, Schrawn, Aran, sings another song I did not want! About the war and the bombs falling (to an old tune) text by her sister who is a nun at St. Louis (in Ireland) [the St Louis order], and must not be mentioned. I did successfully evade another song by a priest, a eulogy, lament on his own loneliness written upon the death of his brother priest on Aran (I probably missed something!) (Cowell 1955).

(3) In 1952, the American folk musician Jane Ritchie (1922-) decided not to bring her recording machine to Aran; instead, her photographer husband George Pickow (1922-2010) took over 300 photographs there for a photo-journal article that would earn them some additional funds to support their year-long tour of Ireland and Britain. When I visited them in Long Island, New York, in 2001, they explained to me that it was probably the lack of electricity that had dissuaded them from bringing the apparatus with them. However, it is worth noting here that they used batteries in the other locations where they recorded in Ireland, so there is still some ambiguity about their motives for not bringing the machine to Aran.

(4) Finally, whilst in Árainn in 1932-3, the American director Robert Flaherty (1884-1952) filmed a local wedding; my grandmother Máire Gill (1913-1999) recalled watching the rushes being projected on the white wall of the house in which she cooked for Flaherty and his family. Though it surely depicted music and dance, the footage was not included in Flaherty's Man of Aran. Clearly, he

temper this judgment with two points: the scope of Munch-Pedersen's book was limited by questions of time and space and he was, therefore, prevented from considering the ways in which Pedersen's collection of songs heralded the changes that modernity was bringing to Aran; and he was simply more interested in the stories than in the songs (In conversation with the author, 29 August 2009). 
wanted to protect the ascetic image he was creating for the silver screen from any dilution. Indeed, on his one and only return visit to Aran in September 1949, Flaherty burned some reels of outtake footage that he found in the attic of the Man of Aran cottage (Hay 1949, 23), but not all of them (Stoney 1978), a fact that speaks doubly to the question of representation.

\section{Conclusion}

In conclusion, what these examples I have given demonstrate is that the representation of music depends very much on the commentator's relationship, not only with the music itself, but also with the place and with the people to which it belongs; that music and place are inextricably linked. The examples demonstrate how notions of what is authentic to the sonic world of Aran have affected the representation of the music of Aran and of the musicality of Aran, as well as the representation of Aran itself. They remind us to listen as well as look at the world around us as we endeavour to make sense of it. Sound and silence, or the absence of sound, are clearly very important in representations of Irishness. This fact needs to inform studies of Irish music and studies of traditional music in particular because it is, of all our musics, the one most closely allied to our landscape and to our identity. It is clear that, for Irish studies, music can certainly be a valuable historical source - its ability to be subversive means it can be wonderfully revealing - but it may also hold the answers to some of our questions about what it means to be Irish. 


\section{Appendix}

Árainn 1947

Feadail san oiche

Mar dhion ar uaigneas,

Mar fhál idir croi is aigne

Ar bhuairt seal,

Ag giorru an bhealaigh

Abhaile ó chuartaiocht,

An tráth seo thiar

Nior chualas.

Ambrán aerach,

Scaradh oiche is lae,

Ó ghroifhear súgach,

Gaisce ard is goití duishláin

Is gach uaill mhaite

Ag scoilteadh clár an chiunais,

Trath a mbiodh gniomh a gaile a shinsear

A $n$-aithris do dhuile an uaignis,

An tráth seo thiar

Nior chualas.

Liú áthais ná aitis

Ó chroi na hóige

Ag caitheamh 'cloch neart'

Mar ba dhual tráthnóna Dombnaigh,

Nó ag cur liathróid san aer

Le fuinneamh an bhuailte,

An tráth seo thiar

Nior chualas.

Ni don óige feasta

An sceirdoileán cúng úd.

\section{Aran 1947}

Whistling at night

As a defence against the eeriness,

A barrier between heart and brain

In a time of disquiet,

Shortening the road

Home from late visiting,

This time in the West

$$
\text { I heard not. }
$$

A lively song,

When day left night behind,

From a tipsy stalwart,

Loud boasts and defiant gestures

And many an arrogant yell

Splitting the length of the silence

While the brave deeds of their forefathers

Were named to the spirits of solitude,

This time in the West

I heard not.

A shout of joy or pleasure

From the heart of the young

As they tossed the great stone,

Their Sunday evening custom,

Or shot a ball in the air

With force behind the stroke,

This time in the West

I heard not.

Not for the young any more,

That narrow windswept island.

Máirtín Ó Direáin, Selected Poems: Tacar Dánta, selected and translated by Tomás Mac Síomóin \& Douglas Sealy (Newbridge, Co. Kildare: The Goldsmith Press, 1984), 16-17. 


\section{Bibliography}

Adams, Ansel, On Our National Parks, Boston, Toronto/ London, Little/Brown, 1992.

Attal, Jacques, Noise: The Political Economy of Music, Theory and History of Literature 16,

Translated by Brian Massumi, Minneapolis, University of Minnesota Press, 1977 [1985].

Attali, Jacques, Bruits: essai sur l'économie politique de la musique, Paris, PUF, 1977.

Blacking, John, How Musical Is Man? (The John Danz Lectures), Seattle, University of Washington Press, 1973.

Clancy, Luke, Sound Stories: Bob Quinn. RTÉ Radio One (11 October 2007).

Ceol na dTonn [Ceoltóirí Árann], From Aran to Montego Bay, Hy-Brasyl Productions, 2001.

Comharchumann Árann (ed.), Tonnta, Cill Rónáin, Árainn, Comharchumann Árann, 1995.

Cowell, Sidney Robertson (ed.), Songs of Aran, Ethnic Folkways Library FE4002, 1957.

Cowell, Sidney Robertson, Notes, Reel 11 FW-ASCH-RR-5257, Sidney Robertson

Cowell Collection, Ralph Rinzler Folklife Archives and Collections, Smithsonian Center for Folklife and Cultural Heritage, Washington D.C., 18 June 1955.

Davidson, Norris, Dancers of Aran/Aran Dance, Zenifilms, 1934.

Doyle, Bill, The Aran Islands: Another World, Dublin, Lilliput Press, 1999.

DoyLe, Colman, All Changed: Fifty Years of Photographing Ireland, Dublin, O’Brien Press, 2004.

Flaherty, Robert. Man of Aran, Gainsborough Pictures, 1934.

HaY, Lorna. "Flaherty returns to Aran”, Picture Post (10 September 1949), 21-3, p. 45.

MacConghail, Muiris. Mórchuid cloch agus gannchuid cré. Script by Breandán Ó hEithir; Music by Raymond Deane; Scannán Chéad Snámha Teo. \& RTÉ, First Run Films, 1988.

Mac Piarais, Pádraig, “Cuairt ar Árainn na Naomh”, Fáinne an Lae, 12 Samhain [November], 1898.

Mason, Thomas H., The Islands of Ireland, Dublin, Mercier Press, 1936.

McNeillie, Andrew, An Aran Keening, Dublin, Lilliput Press, 2001.

Munch-Pedersen, Ole (ed.), Scéalta Mháirtín Neile: Bailiúchán Scéalta ó Arainn, Baile Átha Cliath, Comhairle Bhéaloideas Éireann, 1994.

NFC: National Folklore Collection.

Ní Fhaircheallaigh, Úna, Smuainte ar Árainn, Baile Átha Cliath, Conradh na Gaeilge, 1902.

Ní Fhlathartaigh, Ríonach, Clár Ambrán Bhaile na hInse, Baile Átha Cliath, An Clóchomhar, 1976.

Ní Chonaola, Lasairfhíona, An Raicin Álainn, Lasairfhíona Ní Chonaola LNC001CD, 2002.

Ní Chonaola, Lasairfhíona, Flame of Wine, Lasairfhíona Ní Chonaola LNC002CD, 2005.

Ní Mhiolláin, Treasa, An Clochar Bán, Cló Iar-Chonnachta CIC022, 1989.

Ní Uallacháin, Pádraigín, A Hidden Ulster: People, songs and traditions of Oriel, Dublin, Four Courts Press, 2003.

Ó Conaola, Macdara, The Love Token. MacDara Ó Conala MD001, 2006. 
Ó Direáin, Máirtín, Selected Poems: Tacar Dánta, selected and translated by Tomás Mac Síomóin \& Douglas Sealy, Newbridge, Co. Kildare, The Goldsmith Press, 1984, p. 16-17. O'Flaherty, Tom, Aranmen All. Daingean Uí Chúis, Co. Kerry, Brandon Press, 1934 [1991]. Ó Giolláin, Diarmuid, Locating Irish Folklore - Tradition, Modernity, Identity, Cork, Cork University Press, 2000.

Ó Gramhnaigh, An t-Athair Eoghan, “Ára na Naomh”, Irisleabhar na Gaeilge 3, n 31-32 \& 4, n 35-36, 1889-1890, p. 101-103; p. 126-128; p. 45-48; p. 53-55.

Ó Gramhnaigh, An t-Athair Eoghan, Tuam News/Western Advertiser 14 February, 2 May, 30 May, 6 June, 20 June, 27 June 1890.

Ó hAnluain, Eoghan (ed.), Ón Ulán Ramhar Siar: Máirtín Ó Direáin ag caint ar chúlra saoil cuid dá dhánta. Baile Átha Cliath: An Clóchomhar, 2002.

Ó hAnluain, Eoghan, Máirtín Ó Direáin. Na Dánta. Indreabhán, Cló Iar-Chonnacht, 2010.

Ó hEıтнir, Breandán and Ó hEIтнir, Ruairí (ed.), An Aran Reader, Dublin, Lilliput Press, 1991.

Ó LúIng, Seán, Kuno Meyer 1858-1919: A Biography. Dublin: Geography Publications, 1991.

Robinson, Tim, Stones of Aran: Pilgrimage, London, Penguin Books, 1986 [1990].

Robinson, Tim (ed.), "Place/Person/Book: Synge's The Aran Islands", In The Aran Islands, J.M. Synge, London, Penguin Books, 1992, p. VII-LIII.

Robinson, Tim, Stones of Aran: Labyrinth, Dublin, Lilliput Press, 1995.

Robinson, Tim, Faithful for life unto Aran [Review of An Aran Keening, by Andrew McNeillie]. The Irish Times - Weekend, Saturday 10 March 2001, [http://irishislands. infolarainn.html] (accessed 18 October 2009).

Ronan, Barry, Tráth. Gael Linn CEF 098, 1983.

Schama, Simon, Landscape and memory, New York, Alfred A. Knopf, 1995.

Sheeran, Patrick F., "Aran, Paris and the Fin-de-siècle", In The Book of Aran, ed. Anne Korff, J. W. O’Connell and John Waddell, Kinvara, Co. Galway, Tír Eolas, 1994, p. 299-305.

Sidney Robertson Cowell Collection, Ralph Rinzler Folklife Archives and Collections,

Smithsonian Center for Folklife and Cultural Heritage, Washington D.C.

Spellissey, Seán, Window on Aran, Ennis, The Book Gallery, 2003.

Stoney, George, How the Myth Was Made: a study of Robert Flaherty's 'Man of Aran', Coproduced by George C., Stoney and James Brown, 1976-1978.

Synge, John Millington, The Aran Islands, Introduction essay and notes by Tim Robinson, London, Penguin Twentieth-Century Classics, 1907 [1992].

Various, The Aran Lifeboat Collection, Aran Recordings 01, 2006. 